Global Conferences Series:

Social Sciences, Education and Humanities (GCSSSEH), Volume 2, 2019

The $2^{\text {nd }}$ International Conference on Sustainable Development \& Multi-Ethnic Society

DOI: https://doi.org/10.32698/GCS.01106

\title{
Factors Influencing Non-Chinese Parents Decision in Choosing National-Type Chinese Primary School (Sjkc)
}

\author{
Liong Teen Teen ${ }^{1}$, Mohd Mahzan Awang ${ }^{2}$, Abdul Razaq Ahmad ${ }^{3}$ \& Anuar Ahmad ${ }^{4}$ \\ ${ }^{1234}$ Faculty of Education UKM, MALAYSIA \\ E-mail: 1tteen84@gmail.com
}

\begin{abstract}
National-type Chinese primary schools (SJKC) in Malaysia is more important in their role in the education of pluralism to meet the needs of diverse ethnic students as a result of the increasing response from non-Chinese parents. This paper aims to examine the factors that influence non-Chinese parents to send their children to National-type Chinese primary schools in Malaysia who place greater emphasis on the Chinese language and influence their children's worldview towards community and ethnic relations. The empirical findings show that among the factors that drove non-Chinese parents to send their children to the SJKC were the quality and diversity factors in the SJKC, the ecological environment factors as well as the importance of mastering the Chinese language in the era of globalization. The findings of this study refer to previous studies and scholarly articles. Throughout the explanation, it is hoped that this guide will help to inspire non-Chinese parents in ensuring that their children enjoy a quality education and contribute to the nation in the process of nation-building.
\end{abstract}

Keywords: SJKC, quality, diversity, ecology system theory

\section{Introduction}

The background of the Malaysian structure is influenced by the western colonies. Under British rule, economic factors, the influx of Chinese and Indian migrants have shaped a plural society. This has affected our country's education system early on with the existence of national schools and vernacular schools such as the SJKC (Sivapalan Selvadurai et al, 2015).
Schools play an important role in shaping the nation as a community institution that plays a role in preserving and disseminating the culture of society while providing new knowledge to build and develop the community. The SJKC is increasingly playing a role in the education of pluralism to meet the needs of various ethnic students following the response of non-Chinese parents including Malays, Indians, Bumiputeras in Sabah and Sarawak such as Kadazan and Iban. According to a report by the United Chinese School Teachers' Association (Jiao Zong) in 2015, there were 15\% of students studying in nearly 1,300 SJKCs in the country 
comprising non-Chinese and which numbers increased to $18 \%$ in 2016.

Parents play an important role in children's choice of school as schools determine their children's academics and profession in the future (Su \& Diana, 2019). Parents have the right to choose whether to send their children to a national school in which the language medium is Malay or to send their children to the National-Type Chinese School (SJKC) which places greater emphasis on the Chinese language (Mandarin).

\section{Problem Statement}

The existence of vernacular schools in the country is often regarded as obstacle to the unity of the people. NationalType Chinese School is one of the vernacular schools. There are questions of protesting and defending the vernacular schools. The claim as the source of ethnic segregation is untrue but it is increasingly playing the role of pluralism education to meet the needs of diverse ethnic students. Therefore, it is important to study non-Chinese parents' choices in the SJKC that influence their children's worldview in community and ethnic relations.

In the Malaysian context, the mother tongue should not be a barrier to a multi-ethnic unity. Even in line with the bilingual skills in students' aspirations, it is important that National-Type Chinese Schools play a part in the diversity and quality of the education system in our country. Chinese language (Mandarin) is one of the international languages and its ability to master it brings great benefits. Due to the strong ethnic identity of minority groups and their mother tongue, it is less likely to assimilate ethnic minorities in particular in their language. There are needs for some vernacular schools such as the SJKC to preserve the cultural identity of minorities. Vernacular schools are also able to overcome the shortcomings in the National School in terms of quality of education (Sivapalan Selvadurai et al, 2015). Those non-Chinese children that master the Chinese language will be able to compete better especially in facing global challenges. The advantage of the National-Type Chinese School is that it will be better served by nonChinese parents, which will benefit the country in the process of building a nation based on racial diversity in Malaysia.

\section{Issues}

Education plays an important role in shaping the national identity and eradicating illiteracy among the younger generation. The Chinese community under the influence of Confucianism, the tradition of respect for teachers and emphasized the quality education has been uphold the
Chinese education and the high regard for the educational struggle. The history has shown that the Chinese community has long established Chinese schools through the efforts of Chinese leaders and associations to preserve their cultural and linguistic heritage. This is evidenced by the construction of Chinese schools wherever there are Chinese settlements (Sia Keng Yek, 2005).

National-Type Chinese School (SJKC) is a historical heritage primary school and also a governmentassisted primary school that used the Chinese language as the medium of instruction. The SJKC was an extension of the racial-based vernacular schools in the early British colonial period. During the British occupation, the schools were funded by the British and the Chinese community while textbooks and syllabuses were taken from China at that time. After the independence of Malaysia, the Chinese Vernacular School was taken over by the government and given the name SJKC. The features of the SJKC are similar to the SK in terms of textbooks, syllabus and government-funded teachers. However, the government implemented the classification of "fully aid school" and "capital assistance school" which has limited the provision of SJKC development. In this regard, the SJKC has its own board of directors or school management to enhance the quality of education in the SJKC. The school's governing bodies partnered with the Parents and Teachers Association (PIBG) to raise donations from the community and parents to finance school development expenses, purchase of equipment, cover part of temporary teacher pay, tuition teachers' allowance and pay for utility bills (Dong Jiao Zong, 2011). In this context, the Chinese community and parents in the SJKC are not stingy to contribute to the quality and future of their children's education (Sinar Harian, 2019).

According to a study by Ngien \& Ching (2016), the factors that drive bumiputera students studying in SJKC Sarawak from the perspective of bumiputera parents are different from the perspective of bumiputera students themselves. From a parent's point of view, they want their children to learn the Chinese language because of future job opportunities. But for students, learning the Chinese language does not necessarily have to be directly related to the future, whereas they think by learning it enables them to communicate with the Chinese people around them. The findings of Ngien \& Ching (2016) also show that $70 \%$ of Bumiputera parents send their children to study in SJKC for their own future. Bumiputera parents' students think that if their children can communicate with Chinese people after mastering the Chinese language, this means that it will benefit their children regardless of job or business opportunities in the future. From the children's point of view, most Bumiputera students choose and agree that the "school 
is equipped" due to the location of the SJKC. Most of SJKC's locations are located in or near the city. When conducting a study in SJKC, researchers note that facilities in the SJKC are comprehensive, for example, teachers teaching with multimedia teaching techniques can not only attract the interest of students but also enhance the impact of teacher's teaching in the information technology age. In addition, the findings of the study also show that the majority of Bumiputera students in Sarawak choose "school is very important in student discipline and decision making." This reflects the rigorous administrative and management system in SJKC.

On the other hand, the study of Tan Yao Sua et al (2013) stated that the factor of school effectiveness is a major factor in determining the choice of National-type Chinese Schools among Malay parents. According to the study, it was found that Malay parents who send children to SJKC had high expectations of their children's learning and academic achievement. The findings show that all Malay parents agree that SJKC can produce excellent students in Science and Mathematics subjects. They feel that the high level of discipline in the SJKC is a contributing factor to excellent student academic achievement.

\section{Ecological Systems Theory}

Ecological Systems Theory can explain the phenomenon as the SJKC (National-type Chinese School) is the preferred choice of bumiputera in Malaysia compared to SK (Nationaltype school). The ecological theory encompasses processes of development and growth that are important to one another. According to Bronfenbrenner (1992), there are 5 systems that influence the development of children, namely, microsystem, mesosystem, exosystem, macrosystem and cronosystem. One of the most important points in Bronfenbenner's ecological systems theory is that developmental assessments of children from any subsystem must be child-centered and the child's experience of life is considered a key driver for his or her future character development (Bronfenbrenner, 1998). The development of students' character and attitudes at a young age will tend to focus on the microenvironment. Student's behavior will develop in a negative or positive way depending on the support environment the microsystem provides. In the context of early childhood education institutions, there are elements of the school curriculum that can provide an environment that contributes to the positive development of students.

Therefore, the efforts in implementing the systematic, disciplined and multicultural SJKC education can be linked to the development of student characters and attitudes by providing a safe, comfortable and stimulating environment for student development at a young age.
According to Bronfenbrenner, studying problems based on ecological theory must involve aspects of prediction that represent four components, namely the context of the problem, the people involved, the process and the time. In this regard, the school environment is a socialization agent that is closely integrated into the life of each individual.

\section{Importance of Mastering Chinese Language}

Along with time expansion, foreign language has become one of the must-haves to compete in the world of profession. One of the fastest-growing foreign languages is the Chinese Language. With the rapid growth of China's economy, making Chinese language or Mandarin a second language in the world, many people from other countries are becoming interested and learning the Chinese language for business and learning purposes. In Indonesia, there are also many schools that offer Chinese courses or use the Chinese language as their medium of instruction, from pre-school to high school (Robby et al, 2016). One of the barriers in learning Mandarin is that the Mandarin character is still unfamiliar to some Indonesians.

According to Pietiläinen (2011), a study conducted from 1995 to 2005 to obtain a public opinion on foreign languages deemed useful to Europeans, found that English was the most useful language, followed by German and French. However, the popularity of these three languages has been declining lately, especially German and French. Although Mandarin was at a low level of usage in 1995, its popularity has doubled in 2005 and is expected to increase after 2005 (Pietiläinen, 2011).

The rise of the Chinese economy has increased the status and prestige of the Chinese language globally. According to Nouriel Roubini, an economist at New York University that 'The Chinese language will be the main language of the future' (Petroff, 2014). Jim Rogers, an American businessman and investor, states: "The Chinese language will be the most important language for the next generation as the $21 \mathrm{st}$ century is China's golden age (Youtube, 2009). Rogers also moved his family from New York to Singapore by providing bilingual opportunities in Mandarin and English to her two daughters.

According to the research of Hyeon Seok Kang (2017), although the popularity and prestige of the Chinese language cannot be as high as English in Korea, there are signs that the Chinese language may challenge the English's position in the future. To assess this possibility, Hyeon first described the recent spike of Chinese language in the country, then identified a phenomenon once used only in English but can now be observed in the Chinese language and finally discusses the weakness of the desire to master 
English among Koreans. and was replaced by a simultaneous 'mandarin mania' phenomenon in Korea. The rising status of the Chinese language in Korea is also reflected in the increase in the number of high schools offering the Chinese language classes: $8.8 \%$ in $2000,25.5 \%$ in 2005 and $36.8 \%$ in 2012 .

The popularity of the Chinese language as a foreign language is visible worldwide. In Zimbabwe, Africa, the government announces plans to teach the Chinese language in all government-run schools (Caulderwood, 2015), while in Pakistan, Asia, the government considers the Chinese language as a compulsory subject start from fifth-grade in schools (Crilly, 2011 ). In Saudi Arabia, the introduction of the Chinese language in the syllabus is also said to further enhance the cultural diversity in Saudi Arabia and help to realize the goals to be achieved in the country's education sector for Vision 2030 (Toodia, 2019). In Russia, according to the Russian Federation Service for Supervision of Education and Science, the Chinese language will be tested in the final examination for 9th graders in 2018. The plan is implemented because by 2020, the 11th graders will have to take the Integrated State Examination with college entrance exams. The Chinese language is one of the required subjects to pass. (World of Buzz, 2017).

The research of Lau Su Kia et al (2012) found that the Chinese language teaching and learning methods as a second language enabling interaction between students of different ethnics in local public universities. Overall, the findings of the study showed that 194 people $(61.98 \%)$ out of 313 respondents admitted that their relationship with other ethnic students had improved after learning the Chinese language as second language. In many of the teaching and learning activities discussed, it was found that most nonChinese students interact with students of different ethnics around them. This again proves that teaching and learning Chinese language can indeed encourage interaction between students of various ethnics.

\section{Implications and Recommendations}

Berner (2017) argues that public education is an important channel for building communities of diverse groups and that public schools of pluralism can offer parents a choice in line with their beliefs and meet their children's pedagogical needs. This requires a change in the structure of public education. In the Malaysian context, it must be brought forward into policies and practices that emphasize the national spirit, where one ethnic group is not superior to another and where no ethnic group is excluded (Kaur, 2017). The multicultural content included in the curriculum materials is insufficient (Santhiram, 1997) but the existence of pluralism education may be ideal for public education in a multicultural society. Although pluralism education is not easy to implement, given its political implications and predictions. In this regard, vernacular schools especially the SJKC can serve as a continuation of the pluralism of the educational system in our country.

The enrollment of non-Chinese students into SJKC is increasing year by year. There are also "fewer students school" of SJKC that have $80 \%$ to $90 \%$ of non-Chinese students (Ngien \& Ching, 2016). For the SJKC, if the number of non-Chinese students is increasing, then the question of the burden and difficulty of the teacher in teaching will prevail. Teachers must use bilingualism in their teaching. Non-Chinese students are not like Chinese speakers, they only speak Chinese when they are in school. This has led to the weakening of the Chinese language proficiency of non-Chinese students and progress in learning has been slow. Therefore, support classes for non-native students can be used to help them master the syllabus of learning.

Overall, there is evidence that SJKC across Malaysia will face more difficult challenges in the future. This is because with the government's policies changing for their own political gain and education being turned into a political polemic for the benefit of some politicians. In the interest of national thoughts, it is necessary for SJKC teachers to use more effective teaching and assessment methods to encourage interaction between students of various ethnic. Not only can this stimulate the learning environment but it also promotes a sense of belonging and unity among students of various races and indirectly, especially for non-Chinese students who are able to master the Chinese language more enjoyable and effectively at an early stage.

\section{Conclusion}

National-Type Chinese Schools (SJKC) are more important in the role of pluralism education to meet the needs of diverse ethnic students due to the well response of nonChinese parents in Malaysia. Non-Chinese parents' awareness of the importance to master the Chinese language and the benefits that come from attending the SJKC bring lots of benefits to parties not only the schools and the parents but the students themselves. Non-Chinese students not only can interact in a harmonious way but also understand, learn and tolerate the culture and life of the Chinese ethnic people during their six years studying in SJKC. For the interests of national thoughts, it is very important that unity and a sense of belonging should be nurtured from an early age. Our country should celebrate diversity and make it one of our 
strengths and inculcate the culture as a multilingual community.

\section{References}

[1] Abd Aziz A, Farrah W. M, Aimi K.A \& Nurliana S. 2017. Realiti kepelbagaian kaum ke arah perpaduan nasional pasca merdeka. Malaysia Journal of Social Science. Jilid 2, 2017: 1-24.

[2] Bal Krishna S. 2018. Chinese as a global language: Negotiating ideologies and identities. Global Chinese,2018 4(1): 1-10.

[3] Bronfenbrenner, U. 1992. Ecology systems theory. R.Vasta (eds), six theories of child development:revised formulations and current issues, vol. 6: ms187-249. London, England: Jessica Kingsely Publishers, LTD.

[4] Bronfenbrenner, U \& Morris, P.A. 1998. The ecology of development processes. Dalam R.N Lerner \& W. Danon (Eds). Handbook of child psychology vol. 1. Theoretical models of human developent, ms. 993-1028. New York: Wiley.

[5] Berner A. R. 2017. Pluralism and American public education-No one way to school. NewYork, NY: Palgrave Macmillan.

[6] Caulderwood, K. 2015. 'Zimbabwe proposes compulsory Chinese lessons, stirring controversy.' International Business Times, May 19. Online at http://www.ibtimes.com/zimbabwe-proposescompulsorychinese-lessonsstirring-controversy-1929317. (Accessed February 3,2016).

[7] Crilly, R. 2011. 'Mandarin lessons to become compulsory in Pakistan.' Telegraph, September 20. Online at http://www.telegraph.co.uk/news/worldnews/asia/pakista n/8776353/Mandarinlessons-to-become-compulsory-inPakistan.html. (Accessed February 3, 2016).

[8] Dong Jiao Zong. 2011. Pembangunan Pelbagai Aliran Sekolah Secara Adil Dan Sistematik Untuk Memperkembangkan Kelebihan Dan Kemajuan Negara. Memorandum Dong Jiao Zong kepada Perdana Menteri Malaysia Y.A.B. Dato' Sri Mohd. Najib bin Tun Abdul Razak.

Online

at https://resource.dongzong.my/images/doc/memorandum/ 2011\%20DJZ\%20memorandum_BM.pdf

[9] Hyeon S.K.2017. Is English being challenged by Mandarin in South Korea?English Today, Cambridge. Vol 33 Iss 4: 40-46. doi:10.1017/S0266078417000220

[10] Kaur, N. 2017. National schools are not Islamic schools, education authorities reminded. Retrieved from https://www.freemalaysiatoday.com/category/nation/201 7/12/02/national-schools-are-not-islamic-schoolseducation-authorities-reminded

[11] Lau S.K., Ang L.H., Soon C.T., Law S.B. \& Wong N.L. 2012. Pengajaran dan Pembelajaran Bahasa Cina dalam
Menggalakkan Interaksi Pelajar Berbilang Kaum. Journal of Language Studies. 12(3): 979-997.

[12] Ngien M.N. \& Ching T.H. 2016. Pembelajaran Bahasa Cina di SJK (C): Kajian Kes Pelajar Bumiputer di Negeri Sarawak. Journal of Chinese Literature and Culture : 6384.

[13] Nur Atiqah T.A, Onmg P.L. 2018. Latar Belakang Sejarah Sistem Pendidikan dan Masyarakat Majoriti Minoriti di Malaysia. International Colloquium on Integration Platform, Binding Differences and Diversity (ICIP) : 74-100

[14] Ong P.L, Nur Atiqah T.A. 2018. Pendidikan Sebagai Tapak Integrasi Penggunaan Bahasa Ibunda dan Sekolah Vernakular. International Colloquium on Integration Platform, Binding Differences and Diversity (ICIP) : 4673.

[15] Petroff, A. 2014. 'Dr. Doom is learning Mandarin.' CNN January 24. Online at http://money.cnn.com/2014/01/24/news/economy/roubini -china-mandarin/ (Accessed February 26, 2016).

[16] Pietiläinen J. 2011. Public opinion on useful languages in europe. European Journal of Language Policy, 3, 1-14. doi:10.3828/ejlp.2011.2

[17] Robby K.B., Minny E.Y. \& Yulius H. 2016. Rancang Bangun Aplikasi Pembelajaran Aksara Bahasa Mandarin untuk Anak Pra Sekolah Berbasis Android. Journal Unisbank Semarang : 180-187.

[18] Santhiram, R. 1997. Curriculum materials for national integration in Malaysia: Match or mismatch? Asia Pacific Journal of Education, 17(2): 7-18. doi:10.1080/02188799708547758

[19] Sia K.Y. 2005. SRJK (Cina) dalam sistem pendidikan kebangsaan. Kuala Lumpur. Perbit Universiti Malaysia.

[20] Sinar Harian. 2019. Ibu Bapa di SJKC tidak kedekut. February, 2019. Online at https://www.sinarharian.com.my/article/11099/SIASAT/ PIBG (Accessed Online at http:// February, 2019).

[21] Sivapalan S., Ong P.L., Marsitah M.R., Ong P.H., Ong P.T. \& Badariah S. 2015. Debating Education for Nation building in Malaysia: National School Persistance or Vernacular School Resistance? Geografia Online Malaysia Journal of Society and Space, 11 issue 13 : 1423.

[22] Su H.T \& Diana P.Y.L. 2019. Determinants of Primary School Choice in Malaysia: School Proximity and Ethnicity. Journal of School Choice International Research and Reform : 1-27 https://doi.org/10.1080/15582159.2019.1574464.

[23] Tan Y.S, Kamarudin N, Sezali.M.D. 2013. Parental Choice of Schooling, Learning Processes and Inter-ethnic Friendship Patterns: The Case of Malay Student in Chinese Primary School in Malaysia. International 
Journal of Educational Development (2013) 33 : 325336.

[24] Toodia. 2019. Arab Saudi Akan Masukkan Subjek Bahasa Cina Ke Dalam Silibus Pelajaran. March 3. Online at https://toodia.my/2019/03/03/arab-saudi-akanmasukkan-subjek-bahasa-cina-ke-dalam-silibuspelajaran/ (Accessed Online at http:// March, 2019).

[25] World of Buzz. 2017. Mandarin Will Become A Mandatory Subject For Russians To Pass By 2020. February $3 . \quad$ Online at https://www.worldofbuzz.com/mandarin-will-becomemandatory-subject-russians-pass-2020/ (Accessed Online at http:// February, 2017)

[26] Youtube. 2009. 'Jim Rogers: Teach your children Chinese.' From Jim Rogersblog, February 21. Online at https://www.youtube.com/watch?v=fRfpAAIjEek (Accessed Online at http:// February, 2016) 